\title{
Screening of pregnant women for cervical malignancies
}

\author{
Pooja Singh $^{1 *}$, Vibha Baghel $^{2}$
}

\author{
${ }^{1}$ Department of Obstetrics \& Gynecology, GCS Medical College, Ahmedabad, Gujarat, India \\ ${ }^{2}$ Department of Obstetrics \& Gynecology, Chhattisgarh Institute of Medical Sciences, Bilaspur, Chhattisgarh, India
}

Received: 14 June 2013

Accepted: 29 June 2013

\author{
*Correspondence: \\ Dr. Pooja Singh \\ E-mail: drpsomesh03@yahoo.co.in
}

(C) 2013 Singh P et al. This is an open-access article distributed under the terms of the Creative Commons Attribution Non-Commercial License, which permits unrestricted non-commercial use, distribution, and reproduction in any medium, provided the original work is properly cited.

\begin{abstract}
This study was carried out on a cross-sectional prospective basis on 590 pregnant women attending ante natal OPD in government medical college and hospital over a period of 1 year during their routine ante natal check up for screening cervical malignancies. The data obtained were analysed. $99 \%$ of the cases were less than 30 years of age. No single case of cervical dysplasia or malignancy was reported. Considering that we have limited resources, screening these young patients in whom we expect low incidence of pre cancer or cancerous lesions doesn't appear to be a very good approach.
\end{abstract}

Keywords: Cervical cancer, Pap smear

\section{INTRODUCTION}

Cervical cancer is both a preventable and curable disease and the disease must be attacked on all the fronts. It is preventable by cervical screening and curable if identified at an early stage. Screening by cytology and early treatment constitute the sheet anchor of control of this disease.

Many women with no health insurance undergo medical evaluation only when they are pregnant and in the current health care crises, this may be the only opportunity for routine cervical screening.

About 3,50,000 new cases are identified in developing countries each year, where no organized screening programmes are established and fewer than 1,00,000 in developed countries, where secondary prevention efforts generally are well established. ${ }^{1}$

The aim of this study was to evaluate the efficacy of screening pregnant women for cervical malignancies as a part of their routine health check up.

\section{METHODS}

This study was carried out on a cross-sectional prospective basis on pregnant women attending ante natal OPD in government medical college and hospital over a period of 1 year.

At the initial ante natal evaluation, each woman, after counseling and taking consent, underwent per speculum vaginal examination with careful inspection of the cervix and a screening pap smear as a routine component of the prenatal work up. The relevant detailed information regarding such screened cases was recorded in the proforma.

Exclusion Criteria: Pregnant women presenting with -

1. Threatened abortion

2. Vaginal discharge due to infections

3. Vaginal bleeding due to any cause

Inclusion Criteria: Barring the above exclusion criterias, rest all pregnant women shall be included in this study. 
Method of Study: Papanicolaou test (Surface biopsy test) with cotton tipped swabs and making conventional smears by spreading them directly on glass slides and fixing them with $95 \%$ alcohol and observing under microscope.

\section{RESULTS}

The below table 1 gives information regarding relation of gravidity of ante natal cases with their present age. According to it, most of the cases were primigravidae falling in the age group range of 20-24 years $(25.4 \%)$ and a small percentage (7.8\%) being less than 20 years of age. Only two primi. were of or above 30 yrs. of age. Second gravidae forms the next major group of the study, most of which $(31.4 \%)$ were between $20-29$ yrs. Of age and 5 cases were of $30 \mathrm{yrs}$. or older.
Table 2 shows the comparison of marital duration with the present age of the studied cases. Majority of cases were married for less than 5 yrs. duration, $51 \%$ of whom were of 20 yrs. or older but below $25 \mathrm{yrs}$. of age at the time study, $16 \%$ fell in the age group of 25-29 yrs., $8.9 \%$ were 20 yrs of age or younger and only $1.18 \%$ were older than or of 30 yrs. Next, $2^{\text {nd }}$ bulk forming group had marital duration of less than 10 yrs. among which $5.4 \%$ and $8.47 \%$ cases fell in the age range of 20-24 yrs. and 25-29 yrs. respectively.

No single case of cervical malignancy was reported. Though PAP smear reported as per in the table 3, ruled out the possibility of any intraepithelial lesion in all studied cases, it revealed some information regarding reproductive tract infection.

Table 1: Study of gravida relation with present age.

\begin{tabular}{|c|c|c|c|c|c|c|c|c|}
\hline \multirow{2}{*}{ Age (years) } & \multicolumn{7}{|c|}{ Gravida } & \multirow{2}{*}{ Total } \\
\hline & 1 & 2 & 3 & 4 & 5 & 6 & 7 & \\
\hline$<20$ & $\begin{array}{l}46 \\
7.8 \%\end{array}$ & $\begin{array}{l}7 \\
1.18 \%\end{array}$ & $\begin{array}{l}2 \\
0.3 \%\end{array}$ & 0 & 0 & 0 & 0 & 55 \\
\hline $20-24$ & $\begin{array}{l}150 \\
25.4 \%\end{array}$ & $\begin{array}{l}122 \\
20.6 \%\end{array}$ & $\begin{array}{l}49 \\
8.3 \%\end{array}$ & $\begin{array}{l}9 \\
1.5 \%\end{array}$ & $\begin{array}{l}4 \\
0.6 \%\end{array}$ & 0 & 0 & 334 \\
\hline $25-29$ & $\begin{array}{l}30 \\
5 \%\end{array}$ & $\begin{array}{l}64 \\
10.8 \%\end{array}$ & $\begin{array}{l}39 \\
6.6 \%\end{array}$ & $\begin{array}{l}13 \\
2.2 \%\end{array}$ & $\begin{array}{l}4 \\
0.6 \%\end{array}$ & 0 & 0 & 150 \\
\hline $30-34$ & $\begin{array}{l}1 \\
0.16 \%\end{array}$ & $\begin{array}{l}4 \\
0.6 \%\end{array}$ & $\begin{array}{l}19 \\
3.2 \%\end{array}$ & $\begin{array}{l}6 \\
1 \%\end{array}$ & $\begin{array}{l}3 \\
0.5 \%\end{array}$ & $\begin{array}{l}1 \\
0.16 \%\end{array}$ & 0 & 34 \\
\hline $35-39$ & $\begin{array}{l}1 \\
0.16 \%\end{array}$ & $\begin{array}{l}1 \\
0.16 \%\end{array}$ & $\begin{array}{l}4 \\
0.6 \%\end{array}$ & $\begin{array}{l}5 \\
0.8 \%\end{array}$ & $\begin{array}{l}1 \\
0.16 \%\end{array}$ & 0 & $\begin{array}{l}2 \\
0.3 \%\end{array}$ & 14 \\
\hline $40+$ & 0 & 0 & $\begin{array}{l}2 \\
0.3 \%\end{array}$ & $\begin{array}{l}1 \\
0.16 \%\end{array}$ & 0 & 0 & 0 & 3 \\
\hline Total & 228 & 198 & 115 & 34 & 12 & 1 & 2 & 590 \\
\hline
\end{tabular}

Table 2: Study of marital life in relation with present age.

\begin{tabular}{|c|c|c|c|c|c|c|}
\hline \multirow{2}{*}{$\begin{array}{l}\text { Age } \\
\text { (years) }\end{array}$} & \multicolumn{5}{|c|}{ Marital life (years) } & \multirow{2}{*}{ Total } \\
\hline & $<5$ & $5-10$ & $10-15$ & $15-20$ & $20+$ & \\
\hline$<20$ & $\begin{array}{l}53 \\
8.9 \%\end{array}$ & $\begin{array}{l}2 \\
0.3 \%\end{array}$ & 0 & 0 & 0 & 55 \\
\hline $20-24$ & $\begin{array}{l}301 \\
51 \%\end{array}$ & $\begin{array}{l}32 \\
5.4 \%\end{array}$ & $\begin{array}{l}1 \\
0.16 \%\end{array}$ & 0 & 0 & 334 \\
\hline $25-29$ & $\begin{array}{l}94 \\
16 \%\end{array}$ & $\begin{array}{l}50 \\
8.47 \%\end{array}$ & $\begin{array}{l}6 \\
1 \%\end{array}$ & 0 & 0 & 150 \\
\hline $30-34$ & $\begin{array}{l}7 \\
1.18 \%\end{array}$ & $\begin{array}{l}14 \\
2.37 \%\end{array}$ & $\begin{array}{l}10 \\
1.69 \%\end{array}$ & $\begin{array}{l}3 \\
0.5 \%\end{array}$ & 0 & 34 \\
\hline $35-39$ & 0 & $\begin{array}{l}6 \\
1 \%\end{array}$ & $\begin{array}{l}3 \\
0.5 \%\end{array}$ & $\begin{array}{l}5 \\
0.8 \%\end{array}$ & 0 & 14 \\
\hline $40+$ & 0 & $\begin{array}{l}1 \\
0.16 \%\end{array}$ & 0 & $\begin{array}{l}1 \\
0.16 \%\end{array}$ & $\begin{array}{l}1 \\
0.16 \%\end{array}$ & 3 \\
\hline Total & 455 & 105 & 20 & 9 & 1 & 590 \\
\hline
\end{tabular}


Table 3: Distribution of the cases according to their pap smear report.

\begin{tabular}{|lll|}
\hline PAP report & $\begin{array}{c}\text { No. of } \\
\text { cases }\end{array}$ & Percent \\
\hline NIEL (No intra epithelial lesion) & 590 & $100 \%$ \\
\hline \multicolumn{3}{|c|}{ Additional associated findings } \\
\hline Trichomonas infection & 16 & $2.7 \%$ \\
\hline Gardenerella infection & 2 & $0.3 \%$ \\
\hline Candida infection & 10 & $1.7 \%$ \\
\hline
\end{tabular}

$2.7 \%, 0.3 \%$, and $1.7 \%$ cases suggested Trichomonas infection, Gardenerella infection and Candida infection respectively.

\section{DISCUSSION}

Nevin and Colleagues $1995^{2}$ reported that approximately 1 in 2000 pregnancies is associated with cervical cancer and approx. $3 \%$ of women with cervical cancer were pregnant.

Reported incidence of abnormal PAP smears detected during pregnancy varies with the study population, however, a $1 \%$ to $8 \%$ incidence of abnormal cervical cytology is commonly reported ${ }^{3,4}$ and only approx. $1.4 \%$ of all cervical cancers diagnosed in association with pregnancy. ${ }^{5}$ Mean age of pregnant women with invasive cervical cancer is $31.8 \mathrm{yrs}$.

This study was conducted keeping in mind the casual attitude of Indian women regarding their health check up. But, they do turn up for ante natal check up for ensuring a normal pregnancy with delivery of a healthy baby. This is the opportunity which can be best made use of, in the best interest of such women and all pregnant women should be screened for pre cancerous lesions. As such during pregnancy, the transformation zone is better exposed due to physiological eversion of cervix (also known as pregnancy ectopy) and cervical sampling becomes easier.

In our study, 590 cases were screened during a 1 yr. period and the mean age of pregnant women under study was $23.44 \pm 3.96$ yrs., most of whom were in their second trimester of gestation. $9.2 \%$ cases were younger than 20 yrs. of age and a large proportion of $56.6 \%$ was between
20-24 yrs. of age. None of the pap smears reported any intraepithelial lesion.

In one study conducted in Department of Obstetrics and Gynaecology, Tohoku university, Sendai, Japan by Abe $\mathrm{Y}$, Ito $\mathrm{K}$ et al $2004^{, 6}$ majority of pregnant women screened were under 30 yrs. of age. 28,616 pregnant women were examined over a period of 10 yrs. from 1993-2002 as subjects of the study group and 55\% of them were less than $30 \mathrm{yrs}$. of age and of this study group, only $1.12 \%$ required close examination. Mean age of examination was $29 \pm 4.88$ yrs.

In a number of case control studies risk of cervical cancer was found to be inversely related to age at $1^{\text {st }}$ sexual intercourse, with approx. 2 fold differentials between those with consummation before 16 yrs. of age and those having it after 20 yrs. of age. ${ }^{7}$

In our study, most of the subjects $(74.6 \%)$ were married above 18 yrs. of age delaying their sexual debut. In our study, major proportion of the cases around $81 \%$ were nullipara or primipara having one full term delivery. These might be probable reasons why abnormal pap smear was not detected.

As per the IARC multicentric case control study by Munoz N, Franceschi S, Bosetti C, et al, ${ }^{8}$ a direct association between no. of full term pregnancies and squamous cell carcinoma of cervix was revealed. The odds ratio for cancer risk in women who had 7 or more full term pregnancies, compared with nullipara and women having 1 or 2 full term pregnancies. According to Talebian \& co-workers $(1976)^{9}$ the incidence of abnormal cytology is about $3 \%$, which is similar to that report for non pregnant women.

The overall progression for all stages of cervical cancer during pregnancy is probably similar to that for non pregnant women (Sood \&Sorosky,1998). ${ }^{9}$ American Family of Physicians (2000), women diagnosed during pregnancy \& those diagnosed during puerperium \& the control subjects did not suffer significantly, in age, gravidity, parity or smoking status.

Data from cancer registries in developing countries indicate that $>80-90 \%$ of cervical cancer cases develop in women $35 \mathrm{yrs}$ or older. ${ }^{10}$ Most of the studies in developing countries revealed that avg. age of women with CIS was b/n 35-44 yrs. ${ }^{11}$ The following table 4 gives the estimated costs \& the trained personnel needed using diff. strategies for cervical screening in India. ${ }^{12}$

Table 4: Estimated costs of different strategies for cervical screening in India.

\begin{tabular}{|llll|l|}
\hline Strategy & Cost/Yr & $\begin{array}{l}\text { \% of Annual } \\
\text { Health Budget }\end{array}$ & $\begin{array}{l}\text { \% Cancers } \\
\text { Prevented }\end{array}$ & $\begin{array}{l}\text { Cytotechnician } \\
\text { Needs }\end{array}$ \\
\hline 35-64 yrs. At 5 yr. interval & Rs.355 million & $5.2-6.5 \%$ & - & - \\
\hline 35-64 yrs. At 10 yr. interval & Rs. 188 million & $2.7 \%$ & $50 \%$ & 2200 \\
\hline Once/lifetime & Rs.84.79 million & $1.2 \%$ & $20 \%$ & 824 \\
\hline
\end{tabular}


It is difficult to screen women between ages of 35-64 years at 10 year intervals with the present resources.

Pap smear testing units have been established under the post partum programme in some selected medical colleges. ${ }^{13}$ Analysis of the data from these shows that the large numbers of women visiting the post partum units are young $\&$ less than 30 year of age.

\section{CONCLUSION}

Considering that we have limited resources, screening these young patients in whom we expect low incidence of pre cancer or cancerous lesions doesn't appear to be a very good approach.

One life time screening for every woman between the ages of 35-40 years appears to be the best approach at the moment. Education of the community using various media needs to be built into screening programmes.

\section{REFERENCES}

1. Parkin DM, Pisani P, Ferlay J. Estimates of the worldwide incidence of eighteen major cancers in 1985. Int J Cancer. 1993 Jun 19;54(4):594-606.

2. Nevin J, Soeters R, Dehaeck K, et al. Cervical carcinoma associated with pregnancy. Obstet Gynecol Surv 1995;50:228.

3. Lurain JR, Underwood PB, Rozier JC, et al. Genital malignancy in pregnancy. Am J Obstet Gynecol 1979;129:536.
4. Rivlin ME, Woodliff JM, Bowlin RB, et al. Comparison of cytobrush. J Reprod Med 1993;38:147.

5. Jones WB, Shingleton HM, Russell A, Fremgen AM, Clive RE, Winchester DP, Chmiel JS. Cervical carcinoma and pregnancy. A national patterns of care study of the American College of Surgeons. Cancer. 1996 Apr 15;77(8):1479-88.

6. Abe Y, Ito K, Okamura C, Niikura H, Terada Y, Murakami T, et al. Cervical cytologic examination during physical checkup of pregnant women: cervical cancer screening in women under the age of thirty. Tohoku J Exp Med. 2004 Nov;204(3):221-8.

7. Brinon LA et al. In Principles and Practical of Gynecologic Oncology. Ed. By Hoskins WJ et al, 1992.

8. Munoz N, Franceschi S, Bosetti C, et al. Role of parity and HPV in cervical cancer. Lancet 2002;359:1093-1101.

9. Sood AK, Sorosky J. Invasive cervical cancer complicating pregnancy. Obstet Gynaecol Clin North Am 1998;25:343.

10. Parker DM. Editor, cancer occurrence in 202-05 developing countries Lyon IARC 1986.

11. PATH, Cervical cancer in developing countries. A situational analysis, Seattle 1993.

12. Prabhakar AK. Strategy for control of cervical cancer in India. Acta Universitatis Tamperensis 1992;334A:24-28.

13. NCCP. Directorate General of health services, Ministry of health\& family welfare, Govt. of India, 1984.

DOI: $10.5455 / 2320-1770 . i j r \operatorname{cog} 20130919$

Cite this article as: Singh P, Baghel V. Screening of pregnant women for cervical malignancies. Int $\mathbf{J}$ Reprod Contracept Obstet Gynecol 2013;2:359-62. 